Aksaray University
Journal of Science and Engineering
e-ISSN: 2587-1277
http://dergipark.gov.tr/asujse
http://asujse.aksaray.edu.tr

Research Article

\title{
Optimization of Combined Ozone/Fenton Process on Olive Mill Wastewater Treatment
}

\author{
Aslihan Kirmaci ${ }^{1}$, Ahmet Duyar ${ }^{2}, \operatorname{Vildan}_{\mathrm{Akgul}^{1}}$, Dilek Akman ${ }^{1}$, Kevser Cirik ${ }^{1, *}$ \\ ${ }^{1}$ Department of Environmental Engineering, Kahramanmaras Sutcu Imam University, Kahramanmaras 46100, Turkey \\ ${ }^{2}$ Department of Environmental Engineering, Suleyman Demirel University, Isparta 32200, Turkey
}

-Received Date: 24 Aug 2017

-Revised Date: 07 Jan 2018

-Accepted Date: 13 Feb 2018

-Published Online: 16 Apr 2018

\begin{abstract}
The aim of this study was to investigate the applicability of Fenton process and combined ozone/Fenton process to remove color, soluble chemical oxygen demand $\left(\mathrm{COD}_{\mathrm{s}}\right)$, phenol, and dissolved organic carbon (DOC) from real olive mill wastewater (OMW). The treatability of OMW was investigated in three different study parts. Initially, Fenton process was optimized under varying $\mathrm{H}_{2} \mathrm{O}_{2} / \mathrm{Fe}^{2+}$ molar ratios ranging between 10 and 20 at the constant $\mathrm{H}_{2} \mathrm{O}_{2}$ concentration of $0.5 \mathrm{mM}$. The $\mathrm{H}_{2} \mathrm{O}_{2} / \mathrm{Fe}^{2+}$ molar ratio of 10 was found optimum providing high color $(51.6 \%), \mathrm{COD}_{\mathrm{s}}(58 \%)$, DOC (27.9\%) and phenol removals $(93.9 \%)$. Further, combined ozone/Fenton process was applied under gradually increasing dosages of $\mathrm{Fe}^{2+}$ and $\mathrm{H}_{2} \mathrm{O}_{2}$ reagents at constant $\mathrm{H}_{2} \mathrm{O}_{2} / \mathrm{Fe}^{2+}$ molar ratio of 10 . The high color removal efficiency $(51.6 \%$ color removal for Pt-Co) was obtained at the $\mathrm{H}_{2} \mathrm{O}_{2}$ and $\mathrm{Fe}^{2+}$ molar ratio of 0.5/0.05. Additionally, $\mathrm{COD}_{\mathrm{s}}$, color, DOC and phenol removal efficiencies improved at increasing reagents concentrations. However, the color removal efficiency was adversely affected while no significant difference on $\mathrm{COD}_{\mathrm{s}}$ and phenol removal was observed at higher concentrations of molar concentrations above $0.5 / 0.05$. Additionally, the results indicated that combined process enhanced treatment performance of OMW by $21 \%, 49 \%$ and $22 \%$ in terms of color, $\mathrm{DOC}$ and $\mathrm{COD}_{\mathrm{s}}$ removals, respectively, compared to only-Fenton process. In the rest of this study, combined ozone/Fenton process was optimized under varying ozonation time (60-120 min) at the optimum $\mathrm{H}_{2} \mathrm{O}_{2}$ and $\mathrm{Fe}^{2+}$ molar dosage of $0.5 / 0.05$ obtained from previous parts. Ozonation time significantly affected the treatment performance, and optimum the reaction time was determined as 90 minute in terms of the high treatment productivity and low operating cost resulted from minimum ozone consumption and short reaction time.
\end{abstract}

Keywords

COD removal, Color removal, Ozone/Fenton process, Olive mill wastewater, Phenol removal

"Corresponding Author: Kevser Cirik, kcirik@ksu.edu.tr

2017-2018@Published by AksarayUniversity 


\section{INTRODUCTION}

Olive oil production is one of the most important income sources for the economy of countries in the Mediterranean region and over 450.000 million-tons olive oil are produced per year [1]. Additionally, high volume fresh water with 40-120 L for per tones is consumed in olive oil production and this industry produces approximately $3.0 \times 10^{7} \mathrm{~m}^{3}$ wastewater per year [1-3]. The olive mill wastewater (OMW) is characterized by high concentrations of chemical oxygen demand (COD), biological oxygen demand (BOD), color, suspended solid (SS) and phenolic substances [4]. The discharge without treatment of this hazardous wastewater containing highly toxic phenolic compounds into environment causes adverse and dangerous effects on all living species $[4,5]$. Therefore, many researchers performed the conventional treatment techniques as adsorption [6] coagulation-flocculation [7], filtration [8] and biological processes [9] for treatment of OMW. However, these treatment techniques need advanced oxidation processes (AOPs) as pre or post-treatment methods due to various disadvantage of these methods such as high membrane cost of filtration process [10], high sludge production of coagulationflocculation [11], low color removal efficiency of biological treatment [12] and inability to meet the discharge standards [13]. Therefore, the advanced treatment technologies such as hydrogen peroxide $\left(\mathrm{H}_{2} \mathrm{O}_{2}\right)$, Fenton $\left(\mathrm{Fe}^{2+/} \mathrm{H}_{2} \mathrm{O}_{2}\right)$, Fenton-like $\left(\mathrm{Fe}^{3+/} \mathrm{H}_{2} \mathrm{O}_{2}\right)$, ozone $\left(\mathrm{O}_{3}\right)$, UV and ultrasound has been widely applied in treatment of OMW. However recently, ozone and Fenton process are commonly used as the pre-treatment $[14,15]$ or post-treatment [16] to remove organic matter and color from various industrial wastewaters. Although Fenton oxidation and ozonation in wastewater treatment are effective, these processes alone are insufficient to treat OMW [17]. Therefore, combined ozone/Fenton as a new treatment process $\left(\mathrm{O}_{3} / \mathrm{H}_{2} \mathrm{O}_{2} / \mathrm{Fe}^{2+}\right)$ has been introduced and this process was firstly applied to stabilized solid-waste leachate. This new process offers advantages such as reduction of reaction time and increment of oxidation potential and some researchers have reported that combined ozone/Fenton process is effective in treatment of various wastewaters such as treated stabilized leachate [14], simulated amoxicillin wastewater [16], phenolic wastewater [17]. However, there are few studies [18] on treatment of olive mill wastewaters with combined ozone/Fenton process in literature. Therefore, the main aim of this study was to evaluate the effectiveness of Fenton, ozone and combined ozone/Fenton processes to remove color and $\mathrm{COD}_{\mathrm{s}}$ from real olive mill wastewater under different operational conditions. The system performance was evaluated in terms of organic matter, color, and phenol removals with total suspended solid parameter. 


\section{MATERIALS AND METHOD}

\subsection{Characteristics of Olive Mill Wastewater}

Wastewater was taken from wastewater storage tank of the olive production factory located at Kahramanmaras, Turkey. The characteristics of the raw OMW are illustrated in Table 1. The OMW were stored in a refrigerator at $4^{\circ} \mathrm{C}$ to avoid microbial growth before it is used in these studies.

In our previous studies, acid cracking as pre-treatment process for OMW treatment was optimized under the different operational conditions (various temperature, reaction time and $\mathrm{pH}$ levels). The condition where the $\mathrm{pH}$ of the untreated OMW was adjusted to 1.5 with concentrated $\mathrm{HCl}$ for 30 min was determined to be optimum in terms of the $\mathrm{COD}_{\mathrm{s}}$ and color removals. In this way, around $10 \% \mathrm{COD}_{\mathrm{s}}, 37 \% \mathrm{DOC}, 32 \%$ color $(\mathrm{Pt}-\mathrm{Co})$ and $18 \%$ phenol removals could be achieved (Table 1) [19]. Thus, the acid-cracked wastewater (33927 mg $\mathrm{COD}_{\mathrm{s}} / \mathrm{L}$ and $10120 \mathrm{mg}$ DOC/L) was used through this study.

Table 1. Characteristics of olive mill wastewaters

\begin{tabular}{lccc}
\hline \multirow{2}{*}{ PARAMETERS } & \multirow{2}{*}{ UNIT } & \multicolumn{2}{c}{ VALUES } \\
\cline { 3 - 4 } & & Raw OMW & Acid cracked OMW \\
\hline Soluble Chemical oxygen & $(\mathrm{mg} / \mathrm{L})$ & $38000 \pm 650$ & $33927 \pm 200$ \\
demand $\left(\mathrm{COD}_{\mathrm{s}}\right)$ & $(\mathrm{mg} / \mathrm{L})$ & $16090 \pm 200$ & $10120 \pm$ \\
Dissolved organic carbon $(\mathrm{DOC})$ & $200 \pm 20$ & $164 \pm 13$ \\
Phenol & $(\mathrm{mg} / \mathrm{L})$ & $19750 \pm 300$ & $13350 \pm 120$ \\
& $\mathrm{Pt}-\mathrm{Co}$ & $575 \pm 25$ & $366 \pm 36$ \\
Color & $436 \mathrm{~nm}\left(\mathrm{~m}^{-1}\right)$ & $380 \pm 15$ & $261 \pm 20$ \\
& $525 \mathrm{~nm}\left(\mathrm{~m}^{-1}\right)$ & $250 \pm 15$ & $139 \pm 12$ \\
\hline
\end{tabular}

\subsection{Experimental Design}

In this study, concentrated $\mathrm{FeSO}_{4} \cdot 7 \mathrm{H}_{2} \mathrm{O}$ stock solution were used as the ferrous iron source. The all experiments were performed at room temperature and the treatability of real OMW was evaluated in three parts (Table 2).

In first part of lab-scale experiments, Fenton process was performed using a six-paddle programmable jar tester (VelpScientifica JLT6, Italy). Working volume of $500 \mathrm{~mL}$ and the mixing procedure including a rapid mix period for $5 \mathrm{~min}$ at $150 \mathrm{rpm}$ followed by a slow-stir phase at $30 \mathrm{rpm}$ for $25 \mathrm{~min}$ were used. In this part, the effect of various molar ratios of Fenton reagents $\left(\mathrm{H}_{2} \mathrm{O}_{2} / \mathrm{Fe}^{2+}:\right.$ 10-20) was investigated at the constant $\mathrm{H}_{2} \mathrm{O}_{2}$ concentration of $0.5 \mathrm{M}$. Further, this system was connected to the ozone generator (Opal OG-400, Ankara, Turkey) and ozone gas was continuously given through a diffuser at the flow rate of $1.28 \mathrm{mg} / \mathrm{min}$. Schematic 
diagram of combined ozone/Fenton system is shown in Figure 1. The performance of the combined ozone/Fenton process was evaluated at the gradually increasing $\mathrm{H}_{2} \mathrm{O}_{2}$ and $\mathrm{Fe}^{2+}$ concentrations at ozonation time of $60 \mathrm{~min}$ and $\mathrm{H}_{2} \mathrm{O}_{2} / \mathrm{Fe}^{2+}$ molar ratio of 10 (part II). The last study part, the combined ozone/Fenton process was operated with increasing ozonation times from 60 to 120 min at the optimum $\mathrm{H}_{2} \mathrm{O}_{2} / \mathrm{Fe}^{2+}$ ratio of 10 and $\mathrm{H}_{2} \mathrm{O}_{2}$ and $\mathrm{Fe}^{2+}$ reagent dosages of 1/0.1 obtained from the first two parts of this study. The system performance was evaluated in terms of $\mathrm{COD}_{\mathrm{s}}$, DOC, color, phenol removal efficiencies.

Table 2. Operational conditions

\begin{tabular}{ccccc}
\hline PARTS & $\begin{array}{c}\text { Reaction time } \\
\text { (minute) }\end{array}$ & $\begin{array}{c}\mathbf{H}_{2} \mathbf{O}_{2} / \mathbf{F e}^{2+} \\
\text { molar ratio }\end{array}$ & $\begin{array}{c}\mathbf{H}_{2} \mathbf{O}_{2} \text { and } \mathbf{F e}^{2+} \\
\text { concentrations (M:M) }\end{array}$ & $\begin{array}{c}\text { Ozonation time } \\
\text { (minute) }\end{array}$ \\
\hline \multirow{4}{*}{ Part I } & 30 & 10 & $0.5 / 0.05$ & - \\
& 30 & 12 & $0.5 / 0.041$ & - \\
& 30 & 14 & $0.5 / 0.035$ & - \\
& 30 & 16 & $0.5 / 0.0312$ & - \\
& 30 & 18 & $0.5 / 0.027$ & - \\
\hline \multirow{3}{*}{ Part II } & 30 & 20 & $0.5 / 0.025$ & 60 \\
& 60 & 10 & $0.1 / 0.01$ & 60 \\
& 60 & 10 & $0.25 / 0.025$ & 60 \\
Part III & 60 & 10 & $0.5 / 0.05$ & 60 \\
& 60 & 10 & $0.75 / 0.075$ & 60 \\
\hline
\end{tabular}

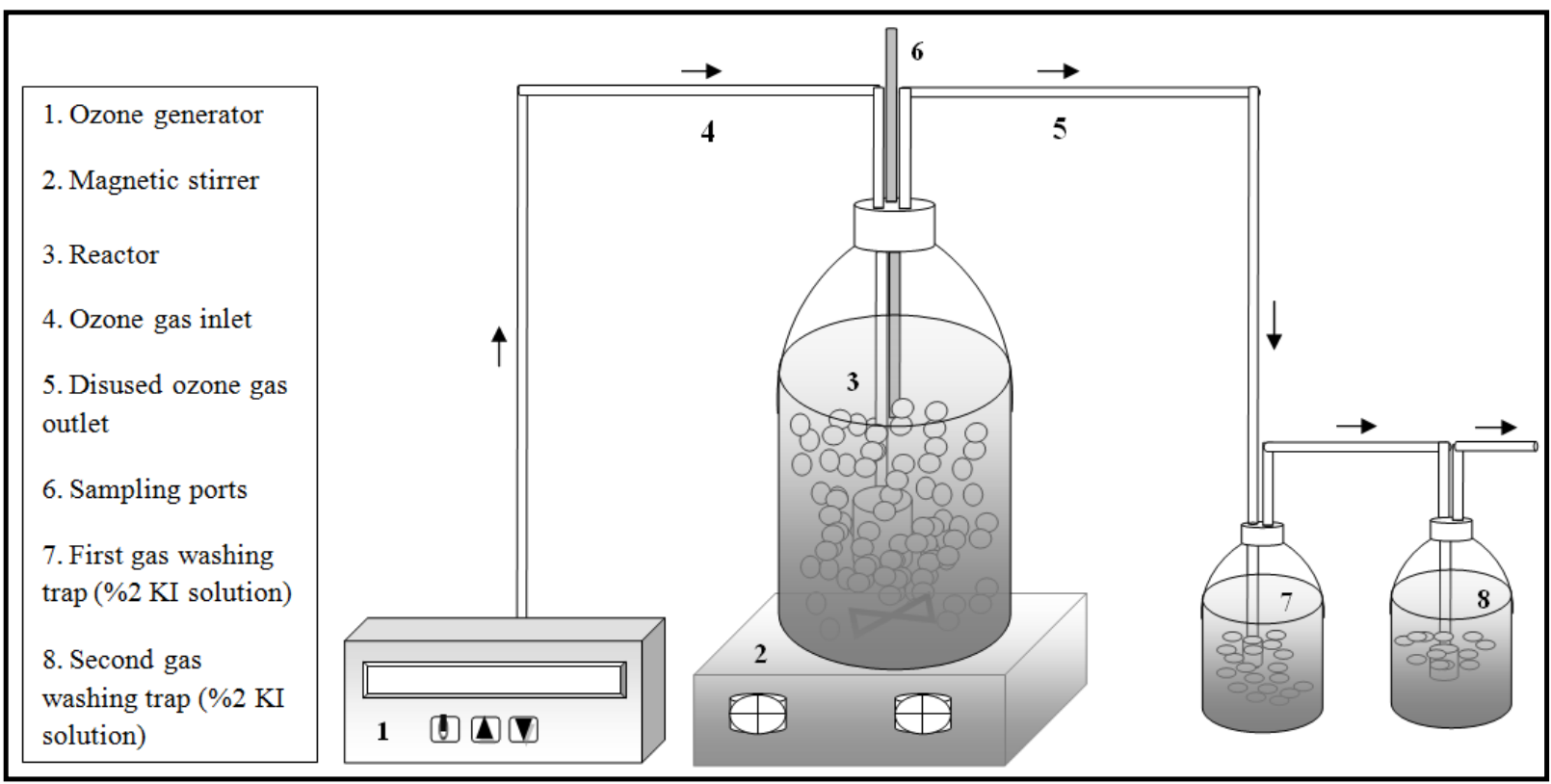

Figure 1. Schematic diagram of lab-scale combined ozone/Fenton process. 


\subsection{Analytical Methods}

Samples centrifuged at $3000 \mathrm{rpm}$ for $5 \mathrm{~min}$ with Eppendorf Centrifuge 514R (Hamburg, Germany) for DOC, $\mathrm{COD}_{\mathrm{s}}$, color and phenol measurements before samples were filtered with Sartorius NY $0.45 \mu \mathrm{m}$ filter (Sartorius AG, Gottingen, Germany). Color, COD and phenol measurements were carried out using HACH DR-5000 UV-VIS spectrophotometer (Cole Parmer Instrument, Loveland, CO., USA). COD values of samples were determined by the dichromate-closed reflux Colorimetric Method, according to Standard Methods approved by USEPA (Standard Methods, 5220 D.). Phenol measurement was carried out using colorimetric method (Standard Methods 5530 Phenol, 5530 B and D, Cleanup Method and Direct Photometric Method, 20th Edition, 1998). Color was measured in two different units as Pt-Co and number of chrominance (RES). Color as Pt-Co unit was spectrophotometrically measured at $465 \mathrm{~nm}$ by Hach Method No. 8025 method approved by USEPA. RES measurements were applied according to the standards of European Norm EN ISO 7887 at three different wavelengths, called $436 \mathrm{~nm}, 525 \mathrm{~nm}$ and $620 \mathrm{~nm}$. These absorbance measurements were used to calculate the spectral adsorption coefficient (RES $(\lambda)$ Eq. 1). A is the absorbance of the sample, $\mathrm{d}$ is the optical path length of the cell $(\mathrm{mm})$ and $\mathrm{f}$ is the conversion factor between $\mathrm{mm}$ and $\mathrm{m}$, which is 1000 .

$$
\operatorname{RES}(\lambda)=(\mathrm{A} / \mathrm{d}) \times \mathrm{f}
$$

DOC analyses were performed in total organic carbon analyser (Shimadzu TOC-VCPN, Kyoto, Japan). pH was measured by a pH meter (Thermo, Orion 4 Star, Indonesia.). Disused ozone concentration in reactor was determined by titrating with $0.1 \mathrm{~N} \mathrm{Na}_{2} \mathrm{~S}_{2} \mathrm{O}_{3}$ solution of ozone absorbed in $2 \% \mathrm{KI}$ solution into gas washing bottles, according to Standard Methods $2350 \mathrm{E}$. Disused ozone was calculated as described by Sevimli et al [20].

\section{RESULTS AND DISCUSSIONS}

\subsection{PART I: Effect of Different $\mathrm{H}_{2} \mathrm{O}_{2} / \mathrm{Fe}^{+2}$ Molar Ratios on Fenton Process Performance}

In this part of the study, Fenton process was alone applied under varying $\mathrm{H}_{2} \mathrm{O}_{2} / \mathrm{Fe}^{2+}$ molar ratios from 10 to 20 with decreasing $\mathrm{Fe}^{2+}$ reagent doses. The $\mathrm{H}_{2} \mathrm{O}_{2}$ concentration, initial $\mathrm{pH}$ level, and reaction time of Fenton process were kept constant at 0.5M, 1.5, $30 \mathrm{~min}$, respectively. The performance of Fenton process in terms of the Pt-Co, RES 620 , COD, phenol, RES ${ }_{436}, \mathrm{RES}_{625}$ and DOC parameters is presented in Fig. 2A, 2B, 2C, 2D, 2E, 2F and 2G, respectively. 


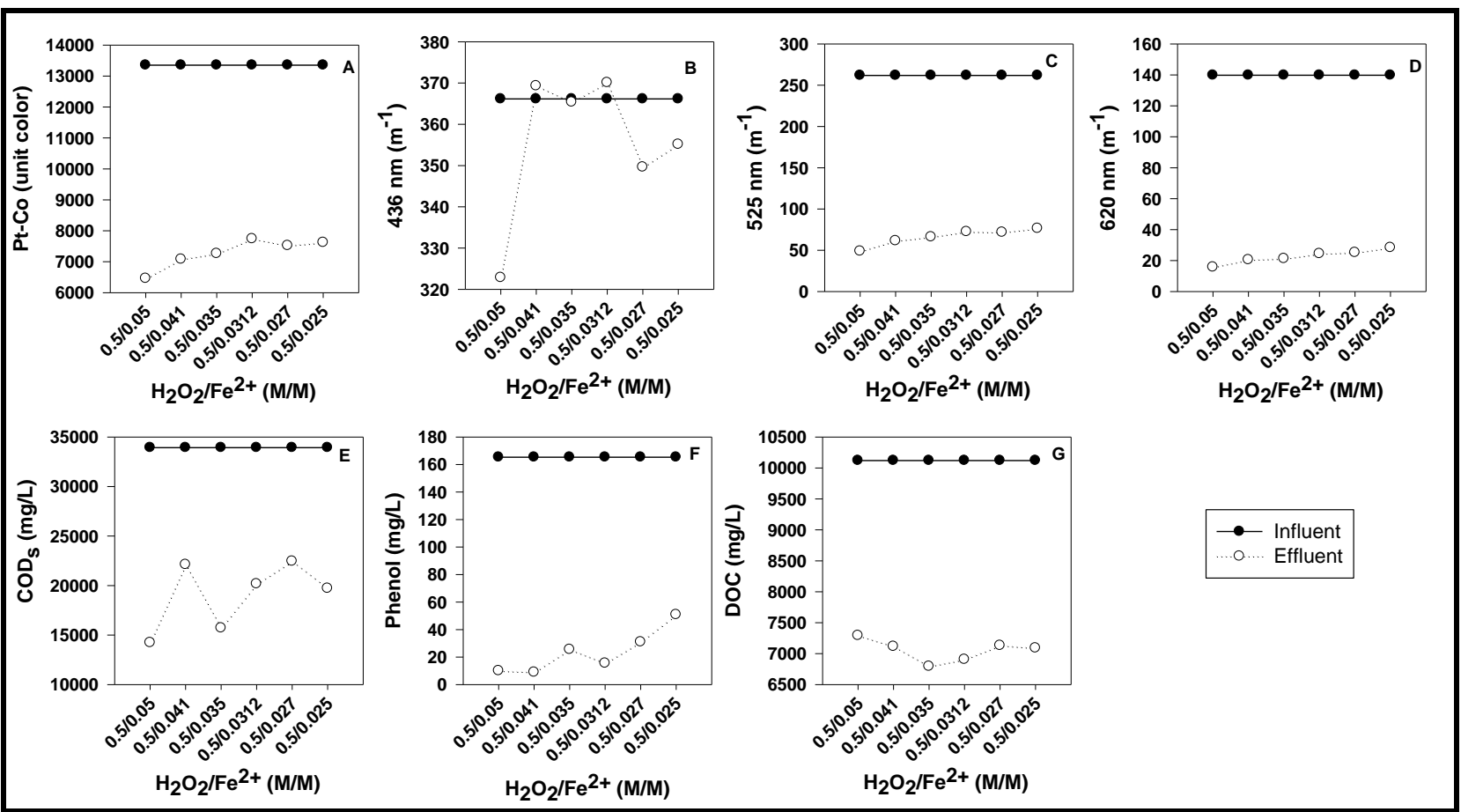

Figure 2: Effect of $\mathrm{H}_{2} \mathrm{O}_{2} / \mathrm{Fe}^{2+}$ molar ratio on color removal as Pt-Co (A), Res436nm (B), Res ${ }_{525 \mathrm{~nm}}(\mathrm{C})$ and $\operatorname{Res}_{620 \mathrm{~nm}}(\mathrm{D}), \mathrm{COD}_{\mathrm{s}}$ removal (E), Phenol removal (F), DOC removal (G).

Decreasing $\mathrm{Fe}^{2+}$ concentration caused a decline in color removal efficiency and color removal as Pt-Co decreased from $51.6 \%$ to $42.9 \%$ at $\mathrm{Fe}^{2+}$ reagent dose of 0.05 and 0.025 , respectively (Fig. 2A). Similar results were also obtained with RES parameters and maximum color removal as $\mathrm{RES}_{436}, \mathrm{RES}_{525}$ and $\mathrm{RES}_{620}$ was $11.8 \%, 81.3 \%$ and $88.7 \%$, respectively, at the $\mathrm{Fe}^{2+}$ reagent dose of 0.05 , corresponding to $\mathrm{H}_{2} \mathrm{O}_{2} / \mathrm{Fe}^{2+}$ molar ratios from 10 . In the conventional Fenton process, the $\mathrm{Fe}^{2+}$ reacts with $\mathrm{H}_{2} \mathrm{O}_{2}$ and hydroxyl radicals that degrade organic matters form [21]. Additionally, the reaction of ozone with $\mathrm{H}_{2} \mathrm{O}_{2}$ generates hydroxyl radicals. However, $\mathrm{H}_{2} \mathrm{O}_{2}$ dissociates into the hydroperoxide ion, which rapidly reacts with ozone when $\mathrm{H}_{2} \mathrm{O}_{2}$ dissolved in water [14]. Thus, low treatment performance obtained in this study probably originated from formation of hydroxyl, which further increased ozone destruction. Similarly, Amr and Aziz [14] indicated that the removal efficiency of the contaminant parameters generally decreased with increasing $\mathrm{H}_{2} \mathrm{O}_{2} / \mathrm{Fe}^{2+}$ molar ratio.

The increasing molar ratio from 10 to 20 adversely affected COD removal performance of system and the COD removal efficiency decreased from $58 \%$ to $41.8 \%$, respectively (Fig. 2E). Similarly, the maximum phenol and DOC removals were observed as $93.9 \%, 27.9 \%$ at $\mathrm{H}_{2} \mathrm{O}_{2} / \mathrm{Fe}^{2+}$ molar ratio of 10 respectively (Fig. $2 \mathrm{~F}$ and $2 \mathrm{G}$ ). These results indicated that low $\mathrm{H}_{2} \mathrm{O}_{2} / \mathrm{Fe}^{2+}$ molar ratio was found favorable for OMW treatment in Fenton process and thus, the subsequent study parts were continued at this ratio. 


\subsection{PART II: Effect of Different Chemical Dosages on Combined Ozone/Fenton Process}

\section{Performance}

In this part of present study, the effect of combined ozone/Fenton process on the treatability of OMW was investigated under different $\mathrm{H}_{2} \mathrm{O}_{2}$ and $\mathrm{Fe}^{2+}$ concentrations at constant ozonation time of 60 min and $\mathrm{H}_{2} \mathrm{O}_{2} / \mathrm{Fe}^{2+}$ molar ratio of 10 . The performance of combined ozone/Fenton with color, DOC, TOC, phenol and ozone profiles is shown in Fig. 3.

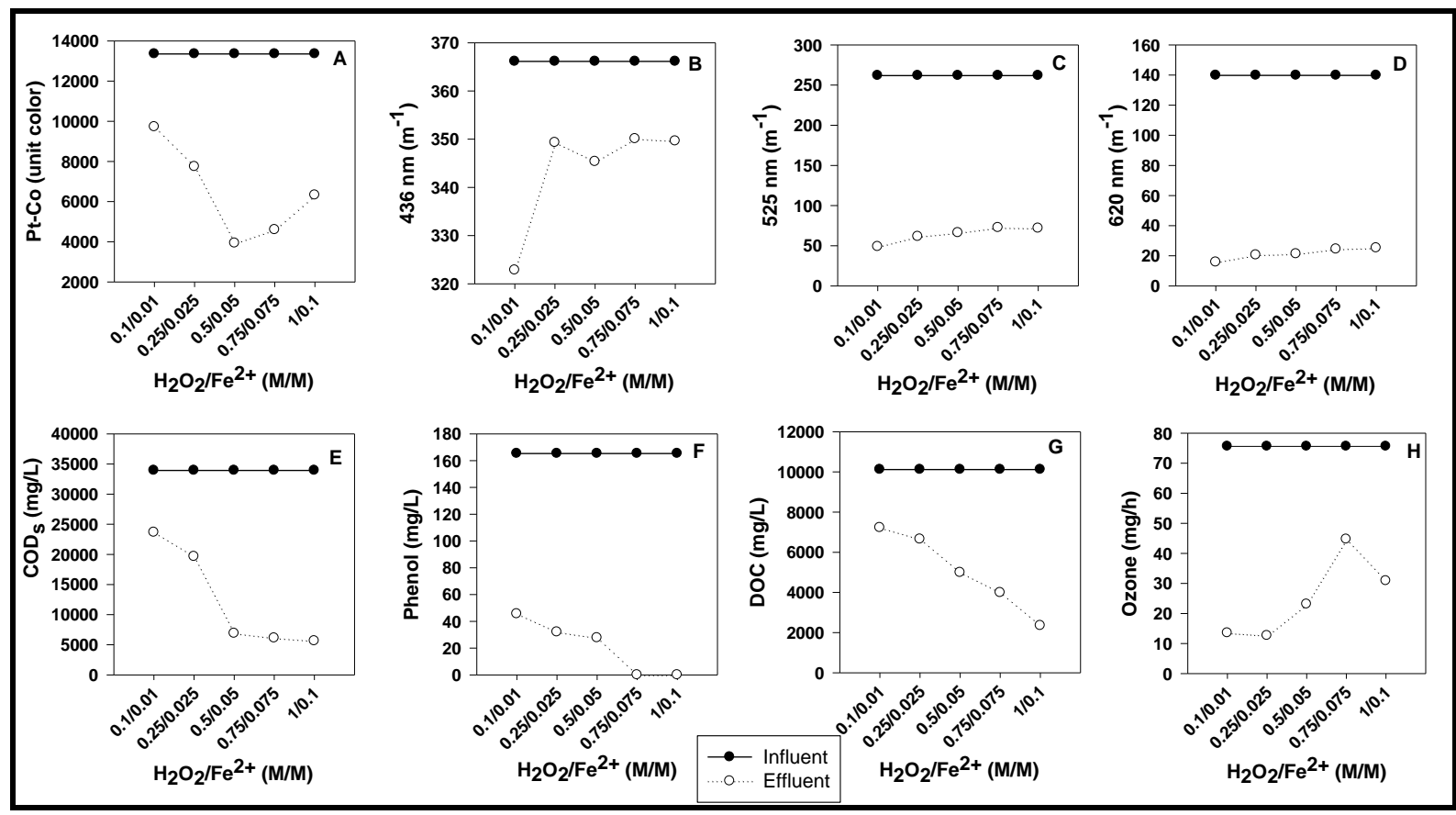

Figure 3: Effect of different chemical dosages on color removal as Pt-Co (A), Res $436 \mathrm{~nm}(\mathrm{~B}), \operatorname{Res}_{525 \mathrm{~nm}}(\mathrm{C})$ and $\operatorname{Res}_{620 \mathrm{~nm}}(\mathrm{D}), \mathrm{COD}_{\mathrm{s}}$ removal (E), phenol removal (F), DOC removal $(\mathrm{G})$, ozone consumption $(\mathrm{H})$.

The color removal efficiency was relatively low at $\mathrm{H}_{2} \mathrm{O}_{2}$ and $\mathrm{Fe}^{2+}$ reagent molar concentrations of $0.1 / 0.01$ and $0.25 / 0.025$, corresponding to $27.2 \%$ and $42 \%$ removal efficiency as Pt-Co, respectively. The color removal efficiency as Pt-Co reached to $70.5 \%$ at increasing $\mathrm{Fe}^{2+}$ and $\mathrm{H}_{2} \mathrm{O}_{2}$ molar concentrations, corresponding to maximum color removal efficiency (Fig. 3A). In this operational condition similarly, the best color removal efficiency as RES $436, \mathrm{RES}_{525}$ and RES $_{620}$ were $24.7 \%, 92.4 \%, 96 \%$, respectively. However, it was observed that color removal efficiency decreased at molar concentrations of both reagents above 0.5/0.05. Additionally, COD removal efficiency improved in the increasing reagents concentration however, no significant difference on COD removal was observed at higher concentration of 0.75/0.075 and 1/0.1, corresponding to around $80 \%$ removal efficiency and $6700 \mathrm{mg} \mathrm{COD} / \mathrm{L}$ effluent value. The increased reagents concentrations had an improving effect on phenol and DOC removal in the combined ozone/Fenton process and all of the phenol present in the wastewater was consumed at the $\mathrm{H}_{2} \mathrm{O}_{2}$ and $\mathrm{Fe}^{2+}$ molar concentrations of $0.75 / 0.075$ and $1 / 0.1$ (Fig. 3F). 
Additionally, DOC removal efficiency reached to $76.8 \%$, corresponding to $2344 \mathrm{mg}$ DOC/L effluent concentration (Fig. 3G). The amount of ozone applied to the system was $75.6 \mathrm{mg} / \mathrm{h}$. High ozone consumption efficiencies were observed at low Fenton reagents molar concentrations of $0.1 / 0.01$ and $0.25 / 0.025$, corresponding to average $82 \%$ consumption yield. Increasing Fenton reagents molar concentrations caused a decrease in ozone depletion and achieved high treatment productivity based on all pollution parameters with lower ozone consumption dosages. The results were similar to that of literature study carried out by Van Aken et al. [22].

This study indicated that the combined process of ozone and Fenton was more effective for the treatment of OMW compared to only-Fenton process. Additionally, the color, DOC and $\mathrm{COD}_{\mathrm{s}}$ removals improved $21 \%, 49 \%$ and $22 \%$ at the same Fenton reagent concentrations with combine process. Kilıç et al. [23] investigated the effect of the advanced oxidation processes containing ozone/ UV, $\mathrm{H}_{2} \mathrm{O}_{2} / \mathrm{UV}$, and ozone/ $\mathrm{H}_{2} \mathrm{O}_{2} / \mathrm{UV}$ on olive oil mill wastewater at a pilot plant. They stated that the ozone $/ \mathrm{H}_{2} \mathrm{O}_{2} / \mathrm{UV}$ process combination showed highest treatment performance among all treatment methods, corresponding to $\mathrm{COD}_{\mathrm{s}}$, phenol and organic carbon removals of $99 \%$. However, they were also indicated that this was not an economic selection for treatability of olive oil mill wastewater.

\subsection{PART III: Effect of Ozonation Times on Combined Ozone/Fenton Process Performance}

In this last part of study, the effect of gradually increasing ozonation times from 60 to $120 \mathrm{~min}$ was evaluated on combined ozone/Fenton process at the optimum $\mathrm{H}_{2} \mathrm{O}_{2} / \mathrm{Fe}^{2+}$ reagents molar dosage of 0.5/0.05 determined in the previous part of the study. The Fig. 4 shows color, DOC, $\mathrm{COD}_{\mathrm{s}}$, phenol and ozone profiles that are changing with increasing ozonation times.

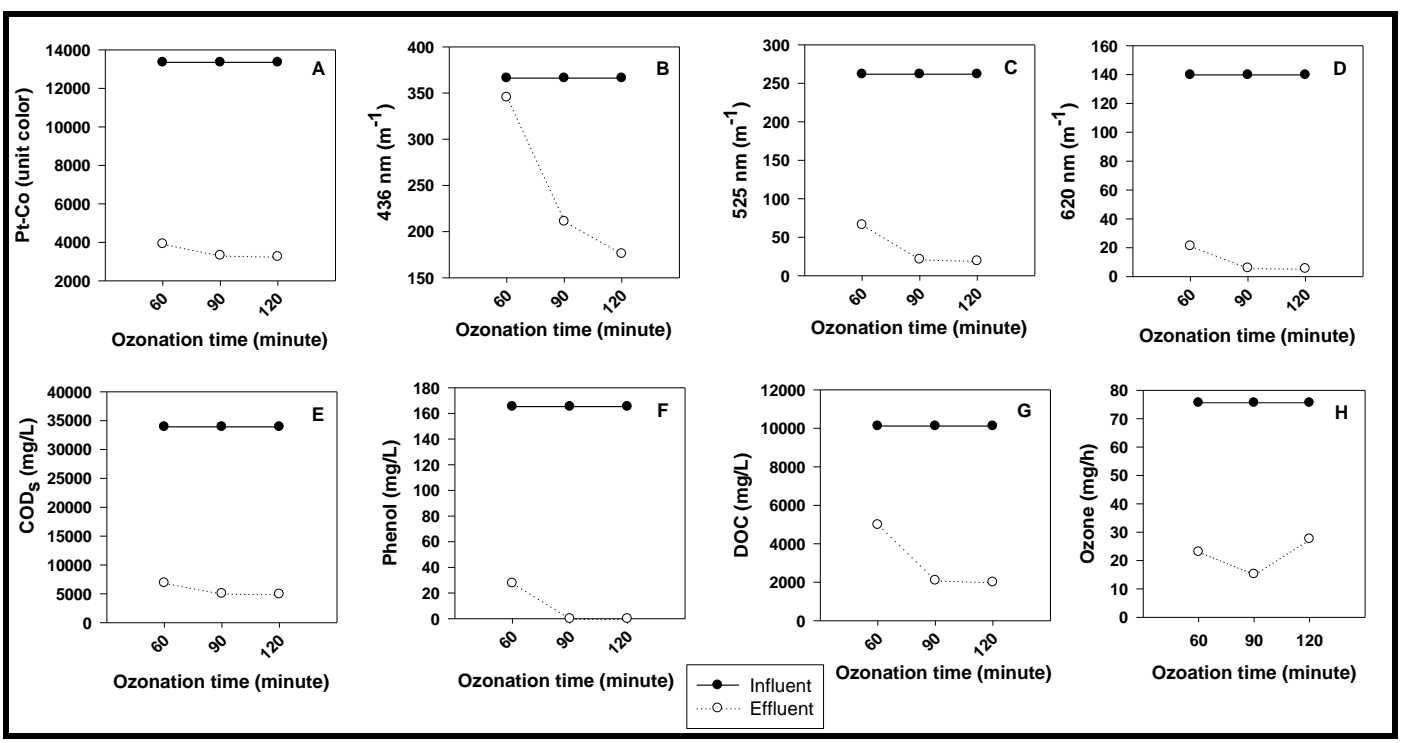

Figure 4: Effect of ozonation times on color removal as Pt-Co (A), $\operatorname{Res}_{436 \mathrm{~nm}}(\mathrm{~B}), \operatorname{Res}_{525 \mathrm{~nm}}(\mathrm{C})$ and Res620nm (D), COD removal (E), phenol removal (F), DOC removal $(\mathrm{G})$, ozone consumption $(\mathrm{H})$. 
In ozonation time of $60 \mathrm{~min}$, the color removal efficiencies as Pt-Co, RES $436, \mathrm{RES}_{525}$ and RES 620 were $70.5 \%, 5.6 \%, 74.7 \%$ and $84.7 \%$, respectively. The color removal efficiency increased distinctly at the increasing ozonation time to $90 \mathrm{~min}$, corresponding to $75.1 \%, 42.3 \%, 91.8 \%$ and $95.7 \%$ removal efficiencies as Pt-Co, RES $_{436}, \mathrm{RES}_{525}$ and $\mathrm{RES}_{620}$, respectively (Fig 4A-D). However, ozonation time over $90 \mathrm{~min}$ did not significantly affect the performance of color removal and efficiency reached to $76 \%$ as Pt-Co. The COD, phenol and DOC profiles showed similar behavior to the color profile and high COD, phenol and DOC removal efficiencies were observed at the reaction time of 90 minute. In this operational condition, consumed ozone amount was also $52.6 \mathrm{mg} / \mathrm{h}$ (Fig. 4H). The reaction time was optimized as $90 \mathrm{~min}$ when considering low operating cost and high reaction performance with minimum reaction time. In a study performed by Amr and Aziz [14] was reported the effectiveness the combine ozone/Fenton process for the treatment of mature landfill leachate. Similar to the optimum ozonation time determined from this study, ozonation time of 90 minute was found optimum and $\mathrm{COD}_{\mathrm{s}}$, color, and $\mathrm{NH}_{3}-\mathrm{N}$ removals were $65 \%, 98 \%$, and $12 \%$, respectively, at $\mathrm{H}_{2} \mathrm{O}_{2}$ and $\mathrm{Fe}^{2+}$ concentrations of $0.05 / 0.05$.

\section{CONCLUSION}

The aim of this study was to evaluate chemical treatability of raw OMW by alone Fenton and combined ozone/Fenton process under different operational conditions. In the alone Fenton process, the maximum treatment performance was achieved in the operational condition containing $\mathrm{H}_{2} \mathrm{O}_{2} / \mathrm{Fe}^{2+}$ molar ratio of 10 at constant influent $\mathrm{H}_{2} \mathrm{O}_{2}$ concentration of $0.5 \mathrm{M}$. This system was converted to a combined ozone/Fenton process by applying ozone gas for $60 \mathrm{~min}$ and combined process resulted in $21 \%, 49 \%$ and $22 \%$ improvement of treatment yield in terms of color, $\mathrm{DOC}$ and $\mathrm{COD}_{\mathrm{s}}$ removals, respectively, compared to only-Fenton process. Ozonation time significantly affected the treatment performance, and the reaction time of 90 minute was found optimum in terms of the high treatment productivity and low operating cost resulted from minimum ozone consumption and short reaction time. However, effluent color and $\mathrm{COD}_{\mathrm{s}}$ values are still not compliant with the discharge standards of $280 \mathrm{Pt}-\mathrm{Co}$ and $250 \mathrm{mg} \mathrm{COD} / \mathrm{L}$ in the Water Pollution Control Regulation of Turkey that was created in 2011[24]. Therefore, this combined process can be used as post or pre-treatment process of the biological treatment processes to achieve the desired water quality.

\section{Acknowledgements}

This work was funded by Scientific Research Project Coordination Unit of Kahramanmaras Sutcu Imam University (Project No: 2014/3-18 YLS). 


\section{References}

[1]B. K. Mert, T. Yonar, M.Y. Kiliç, K. Kestioğlu, Pretreatment studies on olive oil mill effluent using physicochemical, Fenton and Fenton-like oxidations processes. Journal of hazardous materials 174 (2010) 122-128.

[2]S. Khoufi, F. Aloui, S. Sayadi, Treatment of olive oil mill wastewater by combined process electroFenton reaction and anaerobic digestion. Water Research 40 (2006) 2007-2016.

[3]G. Boari, I. M. Mancini, Combined treatments of urban and olive mill effluents in Apulia. Water Science and Technology 22 (1990) 235-240.

[4]N. Adhoum, L. Monser, Decolourization and removal of phenolic compounds from olive mill wastewater by electrocoagulation. Chemical Engineering and Processing: Process Intensification, 43(10) (2004) 1281-1287.

[5]P. Paraskeva, E. Diamadopoulos, Technologies for olive mill wastewater (OMW) treatment: a review. Journal of Chemical Technology and Biotechnology 81(9) (2006) 1475-1485.

[6]M. Achak, A. Hafidi,N. Ouazzani, S. Sayadi, L. Mandi, Low cost biosorbent "banana peel" for the removal of phenolic compounds from olive mill wastewater: Kinetic and equilibrium studies. Journal of Hazardous Materials, 166 (1) (2009) 117-125.

[7]A. Ginos, T. Manios, D. Mantzavinos, Treatment of olive mill effluents by coagulation-flocculationhydrogen peroxide oxidation and effect on phytotoxicity. Journal of Hazardous Materials 133 (1) (2006) 135-142.

[8]E. O. Akdemir, A.Ozer, Investigation of two ultrafiltration membranes for treatment of olive oil mill wastewater. Desalination 249(2) (2009) 660-666.

[9]A.Chiavola, G.Farabegoli,F. Antonetti, Biological treatment of olive mill wastewater in a sequencing batch reactor. Biochemical Engineering Journal 85 (2014) 71-78.

[10]S.C. Santos, R.A. Boaventura, Treatment of a simulated textile wastewater in a sequencing batch reactor (SBR) with addition of a low-cost adsorbent. J. Hazard. Mater. 291 (2015) 74-82.

[11]C. Özdemir, M.K. Öden, S. Șahinkaya, E. Kalipçi, Color removal from synthetic textile wastewater by sonofenton process. Clean-Soil, Air, Water, 39(1) (2011) 60-67.

[12]M. Punzi, A. Anbalagan, R. A. Börner, B. M. Svensson, M. Jonstrup, B. Mattiasson, Degradation of a textile azo dye using biological treatment followed by photo-Fenton oxidation: evaluation of toxicity and microbial community structure, Chemical Engineering Journal, 270 (2015) 290-299.

[13]A. Gunay, D. Karadag, Recent developments in the anaerobic digestion of olive mill effluents. Process Biochemistry 50 (11) (2015) 1893-1903.

[14]S. S. Abu Amr, H. A. Aziz, New treatment of stabilized leachate by ozone/Fenton in the advanced oxidation process. Waste Manag. 32 (2012) 1693-1698.

[15]A. Goi, Y. Veressinina, M. Trapido, Combination of ozonation and the Fenton processes for land fill leachate treatment: evaluation of treatment efficiency. Ozone Sci. Eng. 31 (2009) 28-36.

[16]M. Li, Z. Zeng, Y. Li, M. Arowo, J. Chen, H. Meng, L. Shao, Treatment of amoxicillinby $\mathrm{O}_{3} /$ Fentonprocess in a rotating packed bed. J. Environ. Manage., 150 (2015) 404-411.

[17]Z. Zeng, H. Zou, X. Li, M. Arowo, B. Sun, J. Chen, G. Chu, L. Shao, Degradation of phenolbyozone in the presence of Fentonreagent in a rotatingpacked bed. Chem. Eng. J., 229 (2013) 404-411.

[18]J. Beltran-Heredia, J. Torregrosa, J. Garcia, J. R. Domínguez, J. C. Tierno, Degradation of olive mill wastewater by the combination of Fenton's reagent and ozonation processes with an aerobic biological treatment. Water science and technology: a journal of the International Association on Water Pollution Research, 44 (2001) 103-108.

[19]S. Gocer, B. O. Eskikaya, M. Kozak, A. Duyar, V. Akgul, D. Akman, K. Cirik, Optimization of acid cracking method for olive mill wastewater pre-treatment acid cracking method for olive mill 
wastewater. International Journal of Advances in Science Engineering and Technology 5(3) Spl. Issue-2 (2017) 1-4.

[20]M.F. Sevimli, H.Z. Sarikaya, M. Yazgan, A new approach to determine the practical ozone dose for color removal from textile wastewater. Ozone: Science\&Engineering 25 (2003) 137-143.

[21] D. Hermosilla, M. Cortijo, M.C.P. Huang, Optimization the treatment of landfill leachate by conventional Fenton and photo-Fenton process. Sci. Total Environ. 407 (2009) 3473-3481.

[22]P. Van Aken, N. Lambert, J. Degrève, S.Liers, J. Luyten, Comparison of different oxidation methods for recalcitrance removal of landfill leachate. Ozone Science \& Engineering 33(4) (2011) 294-300.

[23]M. Yalılı Kılıç, T.Yonar, K. Kestioğlu, Pilot-scale treatment of olive oil mill wastewater by physicochemical and advanced oxidation processes. Environmental technology 34(12) (2013) 1521-1531.

[24]http://www.mevzuat.gov.tr/Metin.Aspx?MevzuatKod=7.5.7221\&sourceXmlSearch=\&MevzuatIlisk $i=0$, Water Pollution Control Regulation in Turkey, 2011. 